\title{
The Impact of Social and Emotional Learning Programs on the Emotional Competence and Academic Achievement of Children in Greek Primary School
}

\author{
Thomas Babalis ${ }^{1, *}$, Konstantina Tsoli ${ }^{2}$, Constantinos T. Artikis ${ }^{3}$, Iro Mylonakou-Keke ${ }^{1} \&$ Yota Xanthakou ${ }^{4}$ \\ ${ }^{1}$ Faculty of Primary Education, National and Kapodistrian University of Athens, Greece \\ ${ }^{2}$ Faculty of Primary Education, National and Kapodistrian University of Athens, Greece, Scholar of State Scholarships \\ Foundation \\ ${ }^{3}$ Faculty of Informatics, University of Piraeus, Greece \\ ${ }^{4}$ Faculty of Preschool Education Sciences and Educational Design, University of Aegean, Greece \\ *Corresponding author: Faculty of Primary Education, National and Kapodistrian University of Athens, Greece. \\ Tel: 30-210-368-8463. E-Mail: tbabalis@primedu.uoa.gr
}

Received: October 10, 2013 Accepted: November 26, $2013 \quad$ Online Published: December 9, 2013

doi:10.5430/wje.v3n6p54 URL: http://dx.doi.org/10.5430/wje.v3n6p54

\begin{abstract}
The present study examined the relationship between emotional intelligence, academic achievement and school climate among primary school students. The purpose of the study was to investigate the impact of social and emotional learning programs on the emotional intelligence and the academic achievement of 143 students in the 5th and 6th grade of primary school, who attended relevant programs compared with the corresponding number of students (163) in the same grades, who did not attend such educational programs. Students completed the TEIQue-CSF and a questionnaire with demographic data; in addition, the scores they received in the last quarter (April-June) of the academic year 2011-2012 were taken into account. Combined with the above, a questionnaire was constructed based on the "Checklist for the assessment of the quality of classroom and school climate", in order to investigate the views of the respective teachers on the impact of school climate on the emotional competence of students. The comparative results of the present study showed that there is a positive relationship among the variances. The findings must be taken into account from the Ministry of Education in Greece when designing the curricula in order to create caring, responsible, emotionally and psychosocially balanced students.
\end{abstract}

Keywords: emotional intelligence; emotional competence; social and emotional learning programs; academic achievement; school climate

\section{Introduction}

\subsection{The First Decade of Emotional Intelligence: Conceptual Delimitation}

In 1990 the science of emotional intelligence (EI) was launched, when J. Mayer and P. Salovey published two related articles in journals of academic interest (Mayer, DiPaolo \& Salovey, 1990; Salovey \& Mayer, 1990). In 1995 the term was quickly spread to the general public by D. Goleman, who claimed that "emotional intelligence or intelligence with a heart" justifies why some people are successful in life as opposed to others who may have higher IQ (Goleman, 2009). For almost a decade, researchers are interested in defining the meaning of the concept. Definitions vary depending on the perspective of each scientist and the integration of their theory either in the ability models (Mayer, Salovey, \& Caruso, 2008) or the mixed models (Mayer, Salovey, \& Caruso, 2000). Thus, according to Salovey \& Mayer (1990) emotional intelligence refers to "the ability of perceiving, understanding and using emotions to facilitate thought". Bar-On (2005) uses the term "Emotional-Social Intelligence" and defines it as "an array of non-cognitive skills that determine whether the person will successfully cope with the environmental demands". Goleman (2009) defines emotional intelligence as a competence that gives the person the ability to recognize, understand and use emotional information on the self and others, in order to reach effective performance. 
Mavroveli, Petrides, Shove, \& Whitehead (2008) emphasize on the distinction between "trait EI", as assessed by self-report questionnaires that measure typical performance and "ability EI", which is evaluated through questionnaires that measure maximal performance (Petrides \& Furnham, 2000) and support the first defining it as a set of emotional moods and personal considerations, which relate to feelings and are placed at the lower levels of personality hierarchies (Petrides, Pita, \& Kokkinaki, 2007). In their attempt to avoid the term "intelligence", which refers to ability rather than a trait, they use alternatively the term "emotional self-efficacy" recognizing thereby the inherent subjectivity of the emotional experience (Petrides, 2011). Similarly, other researchers (Ciarrochi, Scott, Deane, \& Heaven, 2003; Saarni 1997) use alternatively the term "emotional competence" to define the individual differences in how people manage effectively emotions and emotionally charged problems. According to Saarni (2000) emotional competence skills follow a developmental path, since each manifests differently at different ages (Saarni, 2011). Such skills, such as self-awareness, self-management, empathy, social awareness, responsible decision making, problem solving, are becoming now more important in the education field (Zins, Elias, Greenberg, \& Weissberg, 2000) reflecting a disengagement from the traditional type of school, according to which the ultimate objective is acquiring knowledge (Lantieri, 2011).

\subsection{The Second Decade of Emotional Intelligence: The Period of Validation}

During the decade of 2000, and while the concept of emotional intelligence has become widespread, research has focused on the valuable results brought about by emotional intelligence in various contexts, such as in the workplace, education, leadership, health, married life, social relations, etc. (Matthews, Zeidner, \& Roberts, 2012). According to the Partnership for 21st Century Skills (2013), students must master the following knowledge, skills and expertise to succeed in work and life in general: a. mastery of core subjects, i.e. language, mathematics, geography, history, b. learning and innovation skills, i.e. critical thinking, problem solving, communication and collaboration, c. information, media and technology skills, d. life and career skills, i.e. flexibility and adaptability, initiative, effective interaction with others. The process that integrates thinking, feeling and behavior in order to achieve important social cues, meet personal and social needs and develop skills that are essential for creating productive members in society is called social and emotional learning (Cohen, 1999; McCombs, 2004). The term "social" reflects the interpersonal development, the emotional aspect the intrapersonal, and the learning suggests that both social and emotional adjustment can be learned through teaching, practice and feedback (Merrell, \& Gueldner, 2010). It is precisely this process of systematic training and implementation of school activities and initiatives that defines the concept of social and emotional learning (Payton, Wardlaw, Graczyk, Bloodworth, Tompsett, \& Weissberg, 2000).

The benefits of implementing such programs are manifold for students. Firstly, skills, such as self-awareness, self-management, social awareness, interpersonal relationships and responsible decision-making, can de taught and contribute positively to the behavior and learning of children (CASEL, 2013). Moreover, attitudes and beliefs about self, others and the school are being improved, which leads to better adjustment, healthy interpersonal relationships, decrease of behavior problems and affective disorders (Greenberg, Weissberg, O 'Brien, Zins, Fredericks, Resnik, \& Elias, 2003; Mylonakou-Keke, 2012). Goleman (2009) claimed that emotional intelligence counts more than IQ for success in school, which led some researchers to the conclusion that social and emotional learning holds a key place in helping students make significant gains in academic achievement (Durlak, Weissberg, Dymnicki, Taylor, \& Schellinger, 2011; Malecki \& Elliott, 2002). However, other researchers are skeptical about the relation between emotional intelligence and academic achievement due to the fact that they find low correlations between the variables (Mavroveli, Petrides, Shove, \& Whitehead, 2008) or because the findings are limited to certain groups of students, for example boys (Petrides, Furnham, \& Frederickson, 2004), or certain educational levels (Laidra, Pullmann, \& Allik, 2007). Consequently, the results remain ambiguous and require further research and study (Lopes \& Salovey, 2004; Zeidner, Matthews, \& Roberts, 2009). Especially, in the Greek area, such research activity is highly limited and fragmented. Daropoulos (2006) found that students who consider themselves as high in emotional intelligence seem to receive high scores in language, mathematics, physics and history. Babalis, Tsoli \& Stavrou (2013) revealed a positive correlation between global score of emotional intelligence and academic achievement in greek language arts. Finally, studies (Hoffman, Hutchinson, \& Reiss, 2009; Platsidou, 2010) have shown that teachers who implement social and emotional learning programs and promote emotional skills cultivate a positive school climate. By focusing on helping students develop social and emotional competency, teachers can improve school climate, which in turn can have positive effects on students' academic achievement (Osher, Spier, Kendziora, \& Cai, 2009).

School climate plays a key role affecting significantly the performance of students as well as their social and emotional development (Freiberg, 2005; Lehr \& Christenson, 2002). According to Haynes, Emmons, \& Comer (1994), school climate concerns the interpersonal relationships which are developed at school and whose quality and 
stability affects the cognitive, social and psychological development of the child. Babalis (2011) defines school climate as the atmosphere which characterizes either the school or the classroom, and has an important impact towards people who are involved in, while Freiberg (2005) emphasizes the positive relationship between teacher and students in creating a positive school climate. One such school climate has positive effects on students' cognitive (Margianti, Fraser, \& Aldridge, 2001; Olweus, 1994) and emotional level as opposed to the negative environment that can hinder the above benefits (Freiberg, 1998; Kuperminc, Leadbeater \& Blatt, 2001). The teacher who encourages his students for high performance and initiatives and aims at their willingness and commitment to the class has considered providing his students with a relaxed learning environment, which is dominated by positive feedback and discovery learning (Babalis, Tsoli, Koutouvela, Stavrou, \& Alexopoulos, 2012). Similarly, the teacher who seeks for his students to accept their emotions and demonstrate social mobilization, while at the same time focuses on promoting individual responsibility and the feeling of security creates the conditions for an efficient, pleasant and serene school climate, thus improving the quality and effectiveness of school (Babalis, Trilianos, Stavrou, Koutouvela, Tsoli, \& Alexopoulos, 2012).

\subsection{The Third Decade of Emotional Intelligence: The Period of Application - Programs in Greek educational Reality}

Emotional Intelligence has now come of age (Goleman, 2013), since we are already undergoing the third decade of its life. Utilizing the scientific legitimacy of the concept and the benefits it brings, emotional intelligence seems geared towards its practical application to achieve positive change. Today hundreds of research projects of emotional literacy are applied to various schools around the world. In particular, in Greece and Cyprus various universal evidence-based prevention programs have been implemented (Chatzichristou, 2005) in formal education, such as the program for the promotion of mental health and learning in the school community (Chatzichristou, 2011), the conflict resolution program "Me and you are becoming We" (Triliva \& Chimienti, 1998), the development of Emotional Intelligence program (Plomaritou, 2004) and the development of social skills: Health Education Program (Anagnostopoulou, Triliva, \& Chatzinikolaou, 2007). The purpose of these programs is the enhancement of social and emotional skills and the promotion of students' psychological resilience. It is noteworthy that since the school year 2011-2012 ninety-six schools in Greece in primary and secondary education are implementing the new pilot curriculum, which includes the scientific field "School and Social Life". Its ultimate goal is to prevent phenomena, such as violence, social exclusion, and promote the physical and mental health and wellness of students within a communicative, cooperative, creative and innovative climate (Pedagogical Institute \& Ministry of Education and Lifelong Learning, 2011). "School and Social Life" consists of four thematic units based on the rationale of projects, which are six in total and each of them covers about five teaching hours in the fifth and sixth grade of primary school. The teaching hours of the subject "Flexible Zone" can additionaly be used at this end enabling the performance of social and emotional activities, which lead to the strengthening of the accountability, self-esteem and ability to adopt positive attitudes in life (Matsaggouras, 2003). The starting point of the current research is driven by the desire to a) investigate the relation between emotional intelligence and academic achievement, since the related literature shows an inconsistency in findings and b) explore the impact of social and emotional learning programs on school climate, especially in the greek area. It is important to note that measuring the impact of evidence-based social and emotional competence programmes underlines the key role of the school in the transition from «I know, I do, I have» to «I am» (Lantieri, 2011).

\subsection{The Purpose of the Study}

The purpose of this study was to investigate the effect of grade-level social and emotional learning programs on the emotional competence and academic achievement of fifth and sixth grade students of primary school who attended relevant programs in comparison with the corresponding number of students of the same classes who did not participate in such programs. It should be emphasized that the evaluation of the programs is beyond the scope of the present study. The specific objectives of the study were:

A) The measurement and comparison of the global score of emotional intelligence in the two groups of students.

B) The measurement and comparison of the academic achievement of the two groups of students in the subjects: Greek Language, Mathematics, History, Social and Political Education and Religious Education.

C) The comparison of the views of teachers who implemented programs of social and emotional learning concerning the cognitive and emotional learning outcomes to that of teachers who have not implemented a corresponding program. 


\section{Method}

\subsection{Participants}

In the present study a sample of three hundred and six (306) students of fifth (147 students, 48.0\%) and sixth grade (159 students, $52.0 \%$ ) participated, of which one hundred and thirty-six were boys (136, 44.4\%) and one hundred and seventy were girls $(170,55.5 \%)$. Of these, one hundred and forty-three students (143, 46.7\%) attended during the school year 2011-2012 a program of social and emotional learning, while one hundred and sixty-three students (163, $53.3 \%$ ) did not attend a corresponding program. Teachers who participated in the survey, which were a total of twenty five (25), were the respective teachers of these students. Four teachers $(4,16 \%)$ were more than thirty years old, four (4, or 16\%) were aged between thirty (30) to thirty-nine (39) years old and finally seventeen $(17,68 \%)$ aged from forty (40) to forty-nine (49) years old. Their overall experience ranged from three (3) to twenty-seven (27) years $(M=16.04, S D=6.96)$, while their experience in the present position was up until twenty five (25) years with a mean of approximately ten years $(M=10.12, S D=7.61)$.

\subsection{Instrumentation}

A) Trait Emotional Intelligence Questionnaire - Child Short Form (TEIQue-CSF) (Mavroveli, Petrides, Shove, \& Whitehead, 2008). This self-report questionnaire is developed for children aged between 8 and 12 years old and includes in the short version 36 items, responded to on a five-point Likert scale $(1=$ Strongly disagree to $5=$ totally agree). The questionnaire assesses the Global Score of Emotional Intelligence of students.

B) Demographics. Students completed a questionnaire which obtained demographic information, such as gender, year of birth, class, ethnicity, parents' job, school location etc.

C) The scores of the third quarter. The scores obtained by the students in the third quarter (April-June) of the school year 2011-2012 were recorded on the following subjects: Greek Language, Mathematics, History, Social and Political Education and Religious Education.

D) Questionnaire based on the "Checklist for the assessment of the quality of classroom and school climate" of Creemers \& Reezigt (2005) and specifically on the dimension "school plan for effectiveness", whose subdimensions are: (1) cognitive student outcomes and (b) affective student outcomes. The questionnaire in its final form consists of two parts. The first part deals with the demographics of teachers and includes information on gender, age, marital status, years of teaching, training and certification in new technologies. The items of the second part seek to appreciate, based on a five-point Likert scale $(1=$ not at all to $5=$ very much), the teachers' contribution in creating a positive climate in the classroom and more specifically in promoting cognitive and affective learning outcomes, on which this research focuses.

\subsection{Procedure of Data Collection}

The research lasted two months and took place at the end of the school year, from May to June 2012, in primary schools in moderate sized cities in the Attica prefecture. Thirteen intervention classrooms were randomly drawn from the eligible schools that implemented social and emotional learning programs for one year and the same number of control classrooms, where no relevant programs were delivered, was also randomly assigned. All students and teachers participated in the research. The researchers visited the schools and asked students and teachers to fill out the questionnaires, giving them the necessary instructions and clarifications. The duration of the students' questionnaires completion was about fifteen (15) minutes, whilst for teachers about twenty (20) minutes. The completion of the questionnaires respected the codes of ethical scientific educational research.

\section{Results}

The Trait Emotional Intelligence Questionnaire - Child Short Form (TEIQue-CSF) was adapted in Greek population by Babalis, Tsoli and Stavrou (2013) with satisfactory indicators of construct validity and reliability. The present study tested the reliability of the questionnaire, where the results showed satisfactory internal consistency index both in the whole sample (Cronbach $a=.80$ ) and individual in the sample of boys (Cronbach $a=.82$ ) and in the sample of girls (Cronbach $a=.79$ ). 
Table 1: Means $(M)$, Standard Deviations $(S D)$ and Differences (t-value) in the Total Score of the Trait Emotional Intelligence Questionnaire - Child Short Form (TEIQue-CSF) based on the Global Score of Emotional Intelligence

\begin{tabular}{lccc}
\hline & Attended a program & Did not attend a program & \\
& $M(S D)$ & $M(S D)$ & $t$-value \\
\hline Emotional Intelligence - Total score & $3.68(0.50)$ & $3.27(0.51)$ & $1.925^{*}$ \\
\hline
\end{tabular}

Table 1 shows the means $(M)$, standard deviations $(S D)$ and the differences (t-value) between the students that participated in social and emotional learning programs and those who did not attend such programs, based on the Global Score of Emotional Intelligence in the total score of the Trait Emotional Intelligence Questionnaire - Child Short Form (TEIQue-CSF). The results showed the existence of statistically significant differences between students who attended a program or participated in activities to promote social and emotional learning and students who did not attend a similar program, with the former showing higher means, which notes that the attendance of the program contributed to the diversification of the students' emotional intelligence.

Table 2: Means $(M)$, Standard Deviations $(S D)$ and Differences (t-value) Based on the Grades in the Subjects: Greek Language, Mathematics, History, Social and Political Education and Religious Education

\begin{tabular}{lccc}
\hline & Attended a program & Did not attend a program & \\
\cline { 2 - 4 } & $M(S D)$ & $M(S D)$ & $t$-value \\
\hline Greek Language & $9.25(0.91)$ & $9.02(0.97)$ & $2.118^{*}$ \\
Mathematics & $9.28(0.91)$ & $9.09(0.96)$ & 1.747 \\
History & $9.37(0.92)$ & $9.18(1.02)$ & 1.724 \\
Social and Political Education & $9.51(0.88)$ & $9.73(0.58)$ & $-2.666^{* *}$ \\
Religious Education & $9.61(0.73)$ & $9.53(0.82)$ & .917 \\
\hline$* p<.05$ & & &
\end{tabular}

Table 2 presents the differences between the two groups of students based on the grades they received in the third quarter in the subjects: Greek Language, Mathematics, History, Social and Political Education and Religious Education. The results showed the existence of statistically significant differences in the subjects of Greek Language and Social and Political Education.

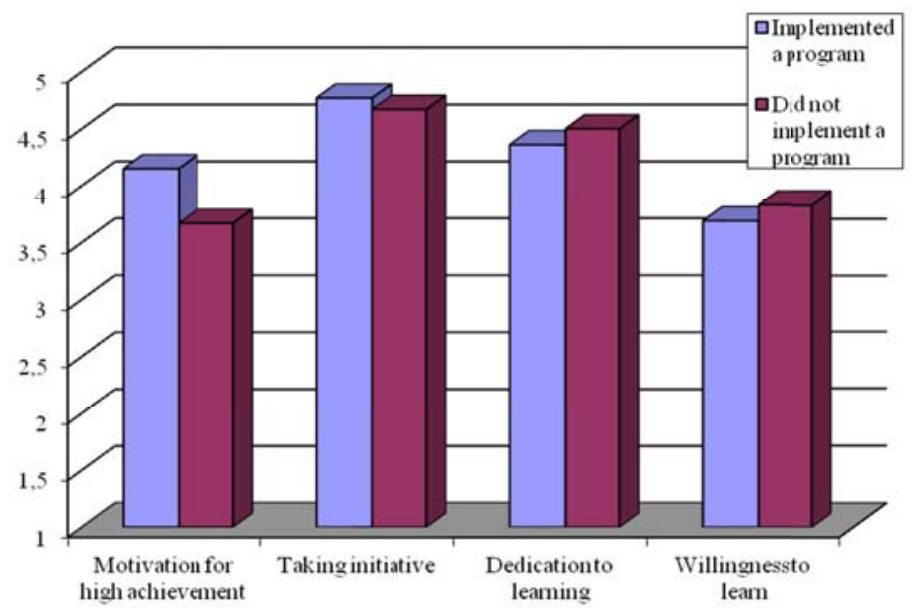

Graph 1: Compare Averages of Responses of Teachers on the Cognitive Learning Outcomes

Graph 1 shows the differences of views between the two groups of teachers on the cognitive learning outcomes pursued in their classroom. The results showed no statistically significant differences between the two groups of teachers. 


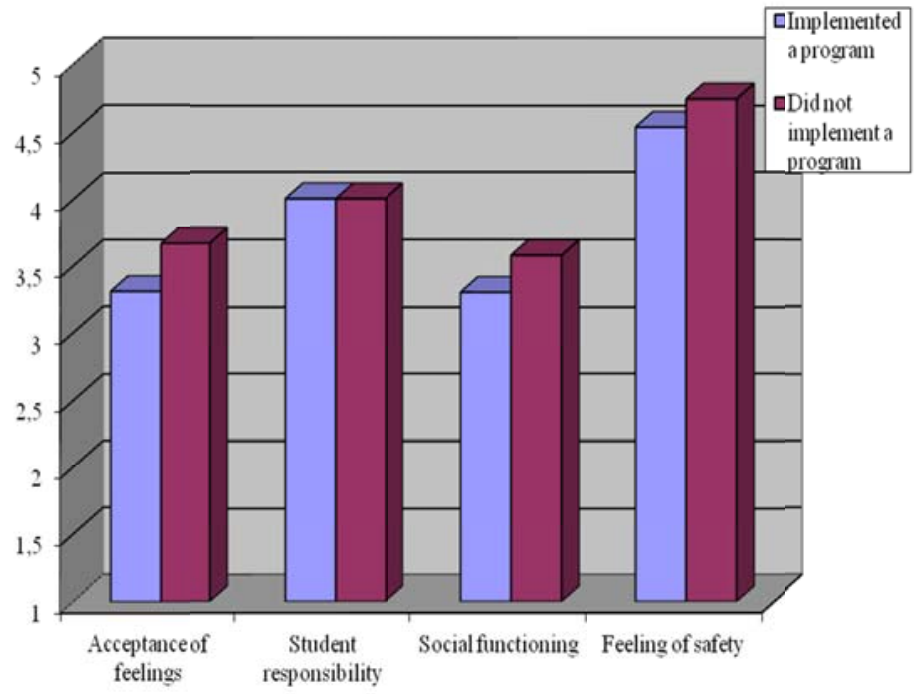

Graph 2: Compare Averages of Responses of Teachers on the Emotional Learning Outcomes

Graph 2 presents the differences of views between the two groups of teachers on emotional learning outcomes pursued in their classroom. The results showed no statistically significant differences between the two groups of teachers.

Table 3: Means $(M)$, Standard Deviations $(S D)$ and Differences (t-value) on the Cognitive-Learning and the Emotional-Learning Outcomes of Teachers

\begin{tabular}{lccc}
\hline & Implemented a program & Did not implement a program & \\
& $M(S D)$ & $M(S D)$ & $t$-value \\
\hline Cognitive-learning outcomes & $4.29(0.30)$ & $4.17(0.33)$ &, 968 \\
Emotional-learning outcomes & $3.79(0.69)$ & $4.00(0.58)$ &,- 823 \\
\hline
\end{tabular}

$* p<.05$

Table 3 shows the differences between the two groups of teachers on the cognitive and emotional learning outcomes sought for the effectiveness of their class.

\section{Discussion}

The results of this study revealed differences in the global score of emotional intelligence of students in fifth and sixth grade of primary school depending on whether they attended a program of social and emotional learning or not. Moreover, a statistically significant difference on the scores of the two groups of students was found in the subjects of Greek Language and Social and Political Education. Regarding the school climate that teachers of both groups support, it appears that they do not differ on the cognitive and emotional learning outcomes they are pursuing.

More specifically, the students who attended a program on social and emotional learning in the school year 2011-2012 were found to have higher Global Score of Emotional Intelligence compared with the students who did not attend a corresponding program, an element which notes that the attendance of the program led to the diversification of emotional intelligence among students. This finding is consistent with research results, according to which exposure to social and emotional learning helps to increase the Global Score of Emotional Intelligence and improves the socio-emotional skills of students (Caldarella, Christensen, Kramer, \& Kronmiller, 2009; CASEL, 2013; Domitrovich, Cortes, \& Greenberg, 2007; Nelis, Quoidbach, Mikolajczak, \& Hansenne, 2009).

Particularly important is the differentiation between the two groups of student on their academic performance in the subject of Greek Language and Social and Political Education. Students who attended a program of social and emotional learning received higher scores on the subject of Greek Language, compared with those who did not participate in a similar program. Plus, the former students received higher scores on the other subjects too, i.e. Mathematics, History and Religious Education. On the other hand, students who attended a program of social and emotional learning ranked lower in the subject of Social and Political Education compared with those who did not participate in a similar program. This finding reinforces the view that emotional intelligence is related to high academic achievement in some subjects, such as mathematics (Parker, Creque, Barnhart, Harris, Majeski, Wood, 
Bond, \& Hogan, 2004), or language arts (Babalis, Tsoli, \& Stavrou, 2013; Petrides, Furnham, \& Frederickson, 2004). Moreover, the content of each subject creates opportunities to reinforce social and emotional skills, with the humanity subjects, such as Language, Literature and History being a wonderful means of implementing emotional literacy activities, because they contain thousands of characters experiencing emotional experiences (Brackett \& Katulak, 2007).

Finally, concerning the views of teachers on school climate and specifically the cognitive and emotional learning outcomes sought and which, according to Creemers \& Reezigt (2005), compose the dimension 'school plan for effectiveness', no statistically significant differences were found in the respective two groups of teachers. The motivation of students for high performance, the encouragement for initiative taking, the pursuit of their dedication to learning and the activation of curiosity and willingness to learn are, from what it appears, cognitive learning outcomes that seek all teachers in the sample. Similarly, all teachers, whether applying a program of social and emotional learning or not, recognize that the acceptance of one's own and others' feelings, students' responsibility for own learning and behavior, social functioning and a feeling of safety contribute to a positive school climate. Goodenow \& Grady (1993) also found that teacher's motivation contributes to a positive school climate, and according to Hammond (2002) a positive school climate is an essential condition for the development of students' feeling of safety.

\section{Conclusion and Recommendations}

Conclusively, according to the results of the present research, social and emotional learning programs do have an effect on the emotional competence and academic achievement of primary school students. Therefore, since social and emotional learning programs can result in an increase in students' emotional intelligence and school performance, they should be incorporated into everyday educational practices. School must provide students with the necessary tools to be successful in school, home, work and life in general. The integration of social, emotional and academic learning in school offers benefits to both their mental health and their academic success (Merrell \& Gueldner, 2010). University has to make the first step, with the integration of the subject "Social and Emotional Learning" in the Curriculum of the Faculties of Primary Education, so that initially students and potential future teachers learn to evaluate their own emotional intelligence (Patti, 2006). Workshops for in-service teachers are also oriented towards this direction, where they can learn about the content of such programs and they provide them with the opportunity to practice the necessary skills for their subsequent implementation in the classroom.

A very important model is the one proposed by CASEL (2013) and illustrates the relationship between the evidence-based programs of social-emotional learning, school success and school climate. Specifically, any intervention for the development of emotional competence of students must be taking place in a supportive learning environment producing it at the same time. Therefore, opportunities to enhance positive attitudes and teach skills are being created, which in turn contribute to the commitment to the school and the reduction of risk behaviors. The final product is improved school achievement and success in school and life in general (Zins, Bloodworth, Weissberg, \& Walberg, 2004).

\section{References}

Anagnostopoulou, T., Triliva, S., \& Chatzinikolaou, S. (2007). Development of social skills: Program of Health Education (dvd). Thessaloniki: Office of Primary Education of East Thessaloniki (in greek).

Babalis, Th. (2011). Classroom Life. Athens: Diadrassi (in greek).

Babalis, Th., Trilianos, Ath., Stavrou, N., Koutouvela, Ch., Tsoli, K., \& Alexopoulos, N. (2012). Good schooling as the outcome of the interaction between children and teachers in greek primary school. US-China education Review B, 6, 602-613.

Babalis, Th., Tsoli, K., Koutouvela, Ch., Stavrou, N., \& Alexopoulos, N. (2012). Quality and effectiveness in greek primary school. Elsevier, Procedia-Social and Behavioral Sciences, 69, 1462-1468. http://dx.doi.org/10.1016/j.sbspro.2012.12.086

Babalis, Th., Tsoli, K., \& Stavrou, N. (2013). Relationship between emotional intelligence and academic performance of primary school students. In F. Kalavassis \& A. Kodakos (Eds.) Topics of Educational Planning: Social networks and school unit: Bridges and meanings, 6, (pp. 204-225). Athens: Diadrassi (in greek).

Bar-On, R. (2005). The Bar-On model of emotional-social intelligence. In P. Fernández-Berrocal and N. Extremera 
(Eds.), Special Issue on Emotional Intelligence. Psicothema, 17, 1-28.

Brackett, M., \& Katulak, N., (2007). Emotional Intelligence in the Classroom: Skill- Based Training for teachers and students. In J. Chiarrochi \& M. Panju (Ed.). 7 Successful Strategies to Promote Emotional Intelligence in the Classroom (pp. 1-27). Great Britain: MPG Books Ltd.

Caldarella, P., Christensen, L., Kramer, T.J., \& Kronmiller, K. (2009). Promoting social and emotional learning in second grade students: A study of the Strong Start curriculum. Early Childhood Education, 37, 51-56. http://dx.doi.org/ 10.1007/s10643-009-0321-4

CASEL (2013). CASEL CUIDE: Effective social and emotional learning programs. Preschool and elementary school edition. Chicago: CASEL. Retrieved February 15, 2013 from: http://casel.org/guide/download-the-2013-guide/

Chatzixristou, X. (2005). Program to promote mental health and learning: Social and Emotional education in school. Athens: Tipothito-Giorgos Dardanos (in greek).

Chatzixristou, X. (2011). Social and emotional education in school: Program to promote mental health and learning in the school community: Educational material II: Primary education 3, 4, 5, 6 grade: Theoretical framework and activities. Athens: Tipothito-Giorgos Dardanos (in greek).

Ciarrochi, J., Scott, G., Deane, F.P., \& Heaven, P.C.L. (2003). Relations between social and emotional competence and mental health: a construct validation study. Personality \& Individual Differences, 35, 1947-1963. http://dx.doi.org/10.1016/S0191-8869(03)00043-6

Cohen, J. (1999). Educating minds and hearts: Social emotional learning and the passage into adolescence. New York and London: Teachers College, Columbia University.

Creemers, B., \& Reezigt, G. (2005). The role of school and classroom climate in elementary school learning environments. In J. Freiberg (Ed.), School climate: Measuring, improving and sustaining healthy learning environments (pp. 30-47). New York, CA: Routledge Falmer.

Daropoulos, A. (2006). Emotional intelligence and academic achievement. Retrieved March 5, 2013 from: http://www.eduportal.gr/index.php/articles/paidagogika/52-sx-epidosi

Domitrovich, C.E., Cortes, R.E., \& Greenberg, M.T. (2007). Improving young children's social and emotional competence: A randomized trial of the preschool "PATHS" curriculum. The Journal of primary prevention, 28(2), 67-91. http://dx.doi.org/10.1007/s10935-007-0081-0

Durlak, J. A., Weissberg, R. P., Dymnicki, A. B., Taylor, R. D., \& Schellinger, K. B. (2011). The impact of enhancing students' social and emotional learning: A meta-analysis of school-based universal interventions. Child Development, 82(1), 474-501. http://dx.doi.org/10.1111/j.1467-8624.2010.01564.x

Freiberg, H. D. (1998). Measuring school climate: Let me count the ways. Educational Leadership, 56(2), 22-26.

Freiberg, H. J. (2005). School climate: Measuring, improving and sustaining healthy learning environments. New York, CA: Routledge Falmer.

Goleman, D. (2009). Emotional Intelligence, Why «EQ» is more important than «IQ»? Athens: Ellinika Grammata (in greek).

Goleman, D. (2013). Emotional Intelligence comes of age. Retrieved May 19, 2013 from: http://www.linkedin.com/today/post/article/20130529194036-117825785-emotional-intelligence-comes-of-age

Goodenow, C., \& Grady, K. E. (1993). The relationship of school belonging and friends' values to academic motivation among urban adolescent students. Journal of Experimental Education, 62(1), 60-71. http://dx.doi.org/10.1080/00220973.1993.9943831

Greenberg, M. T., Weissberg, R. P., O’ Brien, M. U., Zins, J. E., Fredericks, L., Resnik, H., \& Elias, M. J. (2003). Enhancing school-based prevention and youth development through coordinated social, emotional, and academic learning. American Psychologist, 58(6\&7), 466-474. http://dx.doi.org/10.1037/0003-066X.58.6-7.466

Hammond, C.L. (2002). The impact of school climate on students' perceptions about safety. Electronic Doctoral Dissertations for UMass Amherst. Paper AAI3068563. Retrieved March 14, 2013 from: http://scholarworks.umass.edu/dissertations/AAI3068563

Haynes, N. M., Emmons, C., \& Comer, J. P. (1994). School climate survey. New Haven, CT: Yale Child Development Center, School Development Program. 
Hoffman, L.L., Hutchinson, C. J., \& Reiss, E. (2009). On improving school climate: Reducing reliance on rewards and punishment. International Journal of Whole Schooling, 5(1), 13-24.

Kuperminc, G.P., Leadbeater, B.J., \& Blatt, S.J. (2001). School social climate and individual differences in vulnerability to psychopathology among school students. Journal of School Psychology, 39(2), 141-159. http://dx.doi.org/10.1016/S0022-4405(01)00059-0

Laidra, K., Pullmann, H., \& Allik, J. (2007). Personality and intelligence as predictors of academic achievement: a cross-sectional study from elementary to secondary school. Personality of Individual Differences, 42, 441-451. http://dx.doi.org/10.1016/j.paid.2006.08.001

Lantieri, L. (2011, March 20). Our schools resemble factories: they train instead of educate. Diario de Mallorca. Retrieved April 9, 2011 from: http://www.lindalantieri.org/documents/ArticleDiariodeMallorcaLLeditdoc.pdf.

Lehr, C. A., \& Christenson, S. L. (2002). Best practices in promoting a positive school climate. In A. Thomas \& J. Grimes (Eds.), Best practices in school psychology IV (pp. 929-947). Bethesda, MD: National Association of School Psychologists.

Lopes, P.N., \& Salovey, P. (2004). Toward a broader education. In J.E. Zins, R.P. Weissberg, M.C. Wang \& H.J. Walberg (Eds.), Building academic success on social and emotional learning: What does the research say? (pp. 76-93). New York: Teachers College Press, Columbia University.

Malecki, C.K., \& Elliott, S.N. (2002). Children's social behaviors as predictors of academic achievement: A longitudinal analysis. School Psychology Quarterly, 17(1), 1-23. http://dx.doi.org/10.1521/scpq.17.1.1.19902

Margianti, E. S., Fraser, B. J., \& Aldridge, J. M. (2001, April). Classroom environment and students' outcomes among university computing students in Indonesia. Paper presented at the annual meeting of the American Educational Research Association, Seattle, WA.

Matsaggouras, E. (2003). Interdisciplinarity in school knowledge. Athens: Grigoris (in greek).

Matthews, G., Zeidner, M., \& Roberts, R. D. (2012). Emotional Intelligence 101. New York: Springer Publishing Company.

Mavroveli, S., Petrides, K. V., Shove, C., \& Whitehead, A. (2008). Investigation of the construct of trait emotional intelligence in children. European Child and Adolescent Psychiatry, 17(8), 516-526. http://dx.doi.org/10.1007/s00787-008-0696-6

Mayer, J. D., DiPaolo, M. T., \& Salovey, P. (1990). Perceiving affective content in ambiguous visual stimuli: A component of emotional intelligence. Journal of Personality Assessment, 54, 772-781.

Mayer, J. D., Salovey, P., \& Caruso, D. (2000). Models of Emotional Intelligence. In R. J. Sternberg (Ed.), Handbook of Intelligence (2nd ed) (pp. 396-420). New York: Cambridge University Press.

Mayer, J. D., Salovey, P., \& Caruso, D. (2008). Emotional intelligence: New ability or eclectic mix of traits? American Psychologist, 63, 503-517. http://dx.doi.org/10.1037/0003-066X.63.6.503

McCombs, B. L. (2004). The learner-centered psychological principles: a framework for balancing academic achievement and social-emotional learning outcomes. In J.E. Zins, R.P. Weissberg, M.C. Wang \& H.J. Walberg (Eds.), Building academic success on social and emotional learning: What does the research say? (pp. 23-39). New York and London: Teachers College Press, Columbia University.

Merrell, K.W., \& Gueldner, B.A. (2010). Social and emotional learning in the classroom: Promoting mental health and academic success. New York: The Guilford Press.

Mylonakou-Keke, I. (2012). Social and emotional education through sociopedagogical practices. Elsevier, Procedia-Social and Behavioral Sciences, 69, 169-176. http://dx.doi.org/10.1016/j.sbspro.2012.11.396

Nelis, D., Quoidbach, J., Mikolajczak, M., \& Hansenne, M. (2009). Increasing emotional intelligence: (How) is it possible? Personality and Individual Differences, 47, 36-41. http://dx.doi.org/10.1016/j.paid.2009.01.046

Olweus, D. (1994). Annotation: Bullying at school: Basic facts and effects of a school-based intervention program. Journal of Child Psychology and Psychiatry, 35, 1171-1190. http://dx.doi.org/10.1111/j.1469-7610.1994.tb01229.x

Osher, D., Spier, E., Kendziora, K., \& Cai, C. (2009, April). Improving academic achievement through improving school climate and student connectedness. Paper presented at the Annual Meeting of the American Educational Research Association, San Diego, CA. 
Parker, J. D. A., Creque, R. E., Barnhart, D. L., Harris, J. I., Majeski, S. A., Wood, L. M., Bond, B. J., \& Hogan, M. J. (2004). Academic achievement in high school: Does emotional intelligence matter? Personality and Individual Differences, 37, 1321-1330. http://dx.doi.org/10.1016/j.paid.2004.01.002

Partnership for $21^{\text {st }}$ Century Skills (2013). P21 framework definitions. Retrieved March 16, 2013 from: http://www.21stcenturyskills.org

Patti, J. (2006). Addressing social-emotional education in teacher education. In M. Elias \& H. Arnold (Eds.), The educator's guide to emotional intelligence and academic achievement (pp. 67-75). Thousand Oaks, CA: Corwin Press.

Payton, J., Wardlaw, D., Graczyk, P., Bloodworth, M., Tompsett, C., \& Weissberg, R., P., (2000). Social and emotional learning: a framework for promoting mental health and reducing risk behaviours in children and youth. The Journal of School Health, 70(5), 179-185. http://dx.doi.org/10.1111/j.1746-1561.2000.tb06468.x

Pedagogical Institute \& Ministry of Education and Lifelong Learning (2011). New school: School and Social Life, Teacher's guide. Athens (in greek).

Petrides, K. V. (2011). Ability and Trait Emotional Intelligence. In T. Chamorro-Premuzic, S. von Stumm. \& A. Furnham (Eds.), The Wiley-Blackwell Handbook of Individual Differences (1st ed.) (pp. 656-678) New York: Wiley.

Petrides, K. V., \& Furnham, A. (2000). On the dimensional structure of emotional intelligence. Personality and Individual Differences, 29, 313-320. http://dx.doi.org/10.1016/S0191-8869(99)00195-6

Petrides, K. V., Furnham, A., \& Frederickson, N. (2004). Emotional intelligence. The Psychologist, 17(10), 574-577.

Petrides, K. V., Pita, R., \& Kokkinaki, F. (2007). The location of trait emotional intelligence in personality factor space. British Journal of Psychology, 98, 237-289. http://dx.doi.org/10.1348/000712606X120618

Platsidou, M. (2010). Emotional intelligence: theoretical models, methods of measurement and applications in education and work. Athens: Gutenberg (in greek).

Plomaritou, V. (2004). Program of developing emotional intelligence. Athens: Grigoris (in greek).

Saarni, C. (1997). Emotional competence and self-regulation in childhood. In: P. Salovey \& D.J. Sluyter (Eds.), Emotional Development and Emotional Intelligence: Educational Implications (pp.35-69). New York: Basic Books.

Saarni, C. (2000). Emotional competence: A developmental perspective. In R. Bar-On \& J. D. A. Parker (Eds.), The Handbook of Emotional Intelligence (pp. 68-90). San Francisco: John Wiley \& Sons, Inc.

Saarni, C. (2011). Emotional development in childhood. In R. E. Tremblay, M. Boivin, \& RDeV. Peters (Eds.), Encyclopedia on early childhood development (pp.1-7). Montreal, Quebec: Centre of excellence for early childhood development and strategic knowledge cluster on early child development.

Salovey, P., \& Mayer, J. D. (1990). Emotional intelligence. Imagination, Cognition, and Personality, 9, 185-211. http://dx.doi.org/10.2190/DUGG-P24E-52WK-6CDG

Triliva, S, \& Chimienti, G. (1998). Conflict control program: handbook for psychologists, teachers and social workers who want to enhance childrens' emotional intelligence. Athens: Ellinika Grammata (in greek).

Zeidner, M., Matthews, G., \& Roberts, R.D. (2009). What we know about emotional intelligence: How it affects learning, work, relationships, and our mental health. Massachusetts: The MIT Press.

Zins, J.E., Elias, M.J., Greenberg, M.T., \& Weissberg, R.P. (2000). Promoting social and emotional competence in children. In K.M. Minke \& G.C. Bear (Eds.), Preventing school problems-promoting school success: Strategies and programs that work (pp. 71-100). Bethesda, MD: National Association of School Psychologists.

Zins, J.E., Bloodworth, M.R., Weissberg, R.P., \& Walberg, H.J. (2004). The scientific base linking social and emotional learning to school success. In J.E. Zins, R.P. Weissberg, M.C. Wang \& H.J. Walberg (Eds.), Building academic success on social and emotional learning: What does the research say? (pp. 3-22). New York: Teachers College Press, Columbia University. 